\title{
KARAKTERISTIK TELUR TETAS PARENT STOCK AYAM BROILER YANG DIFUMIGASI DAN TANPA FUMIGASI
}

\author{
Fifi Hariani ${ }^{1}$, Muh. Amrullah Pagala ${ }^{2}$, Rahim Aka ${ }^{2}$ \\ ${ }^{1}$ Alumni Jurusan Peternakan FPT UHO \\ ${ }^{2}$ Dosen Jurusan Peternakan FPT UHO \\ Email : amroe74@gmail.com
}

\begin{abstract}
ABSTRAK
Penelitian ini bertujuan untuk mengetahui karakteristik telur tetas parent stock ayam broiler yang difumigasi dan tanpa fumigasi. Penelitian ini dilaksanakan di PT. Mega Satwa Perkasa, Desa Todopulia, Kecamatan Tanralili, Kabupaten Maros, Sulawesi Selatan, pada bulan September 2016. Secara umum penelitian dilaksanakan dua tahap yaitu tahap persiapan fumigasi dan tahap pengumpulan data. Telur tetas dibagi dalam dua perlakuan, yaitu telur tetas yang difumigasi dan telur tetas tanpa fumigasi. Setiap perlakuan diulang sepuluh kali, sehingga terdapat 20 unit percobaan dan setiap unit menggunakan 10 butir telur sehingga telur tetas yang digunakan berjumlah 200 butir. Parameter yang diamati pada penelitian ini yaitu fertilitas, daya tetas dan hasil tetas. Berdasarkan hasil penelitian dapat disimpulkan bahwa telur tetas yang difumigasi dan tanpa fumigasi tidak berpengaruh nyata $(p>0,05)$ terhadap fertilitas, daya tetas dan hasil tetas.
\end{abstract}

Kata kunci : Telur tetas, Parent stock ayam broiler, Fumigasi.

\begin{abstract}
This study aims to determine the characteristics of hatching eggs parent stock of broiler chickens fumigated and nonfumigated. This research was conducted at PT. Mega Satwa Perkasa, Todopulia Village, Tanralili Sub-district, Maros Regency, South Sulawesi, in September 2016. In general, the research was conducted in two phases, namely the preparation phase of fumigation and the data collection phase. Hatching eggs are divided into two treatments, namely the fumigated hatching egg and the hatching egg without fumigation. Each treatment was repeated ten times, so there were 20 experimental units and each unit used 10 eggs so that the hatching eggs used amounted to 200 grains. Parameters which are observed in this study were fertility, hatchability and hatching result. Based on the result of this research, it can be concluded that fumigated and fumigated hatching eggs have no significant effect $(p>0,05)$ on fertility, hatchability and hatching result.
\end{abstract}

Key words: Hatching egg, Parent stock of broiler chicken, Fumigation. 


\section{PENDAHULUAN}

Meningkatnya perkembangan industri peternakan disebabkan karena semakin meningkatnya jumlah penduduk dan meningkat pula kesadaran masyarakat akan pentingnya kebutuhan gizi khususnya protein hewani. Daging unggas dan telur merupakan sumber protein hewani yang berasal dari industri perunggasan. Salah satu industri perunggasan yang bergerak dalam menghasilkan daging dan telur adalah breeding farm.

Breeding farm di industri perunggasan merupakan salah satu faktor penunjang usaha peternakan khususnya pada peternakan parent stock ayam broiler. Dalam perusahaan pembibitan sangat penting untuk melakukan penyediaan bibit. Bibit ayam secara genetik dipengaruhi oleh beberapa gen penting seperti gen GH untuk pertumbuhan dan produksi telur (Pagala dkk, 2013; pagala dkk, 2015)..

grand parent stock ayam broiler secara teratur dan kontinyu. Usaha pembibitan tidak akan berkembang dengan baik tanpa adanya manajemen penetasan yang baik. Penetasan merupakan bagian dari kegiatan pembibitan yaitu untuk mempertahankan dan meningkatkan populasi DOC, keberhasilan penetasan salah satunya yaitu ditentukan oleh kualitas telur.

Kerabang telur merupakan salah satu faktor yang mempengaruhi kualitas telur. Kerabang telur merupakan lapisan terluar dari telur. Kerabang telur memiliki fungsi yaitu mencegah terjadinya kontaminasi dari mikroorganisme yang dapat mempengaruhi embrio dalam telur, sehingga kebersihan kerabang telur sangat penting untuk dijaga. Salah satu upaya yang dapat dilakukan adalah dengan melakukan fumigasi telur tetas.

Fumigasi adalah proses pembersihan telur bertujuan untuk membunuh atau mengurangi kontaminasi mikroorganisme yang melekat atau menempel pada permukaan telur. Fumigasi biasa dilakukan pada penetasan (hatchery) di breeding farm, khususnya pada industri perunggasan. Fumigasi sangat penting untuk dilakukan agar embrio yang ada dalam telur tetas terhindar dari kontaminasi mikroorganisme yang dapat menyebabkan kematian embrio. Telur tetas yang tidak dimasukan kedalam ruang fumigasi kemungkinan akan berdampak negatif pada kerabang telur, disebabkan mikroorganisme akan merusak kerabang telur dan pada akhirnya embrio dalam telur juga akan terserang oleh mikroorganisme yang menyebabkan kematian pada embrio dan telur tetas dengan cepat membusuk, kandungan bakteri yang tinggi menyebabkan telur explode karena bakteri pada embrio yang mati mengeluarkan $\mathrm{CO}_{2}, \mathrm{NH}_{3}, \quad \mathrm{~N}_{2}$, dan $\mathrm{H}_{2} \mathrm{~S}$ (Mukhlisah, 2014). Oleh karena itu perlu dilakukannya penelitian mengenai karakteristik telur tetas parent stock ayam broiler yang difumigasi dan tanpa fumigasi.

\section{MATERI DAN METODE}

\section{Materi}

Penelitian ini mengggunakan telur parent stock ayam broiler sebanyak 200 butir dengan pembagian telur fumigasi 100 butir dan tanpa fumigasi 100 butir, $\mathrm{KMnO} /$ kalium permanganate atau Pottassium carbonat 250 gram, dan $\mathrm{H}_{2} \mathrm{CO} /$ Formalin $500 \mathrm{ml}$.

\section{Metode}

Secara umum penelitian dilaksanakan dua tahap yaitu tahap persiapan fumigasi dan tahap pengumpulan data. Telur tetas dibagi dalam dua perlakuan, yaitu telur tetas yang difumigasi dan telur tetas tanpa fumigasi. Setiap perlakuan diulang sepuluh kali, sehingga terdapat 20 unit percobaan dan setiap unit menggunakan 
10 butir telur sehingga telur tetas yang digunakan berjumlah 200 butir.

\section{HASIL DAN PEMBAHASAN}

\section{A. Persentase Fertilitas Telur Parent Stock Ayam Broiler}

Fertilitas dihitung berdasarkan perbandingan telur yang fertil atau banyaknya telur yang dibuahi dengan jumlah telur yang ditetaskan dikalikan $100 \%$. Fertilitas telur tetas parent stock ayam broiler pada telur yang difumigasi dan telur yang tidak difumigasi dapat dilihat pada Tabel 1.

Tabel 1. Persentase Fertilitas Telur Parent Stock Ayam Broiler yang di Fumigasi dan Tanpa Fumigasi (\%)

\begin{tabular}{ccc}
\hline Ulangan & \multicolumn{2}{c}{ Perlakuan } \\
\cline { 2 - 3 } 1 & $\begin{array}{c}\text { Telur tetas yang } \\
\text { difumigasi }\end{array}$ & Telur tetas yang tidak difumigasi \\
2 & 100 & 90 \\
3 & 100 & 100 \\
4 & 100 & 100 \\
5 & 90 & 100 \\
6 & 100 & 70 \\
7 & 90 & 90 \\
8 & 100 & 80 \\
9 & 100 & 90 \\
10 & 90 & 90 \\
Rataan & 90 & 80 \\
\hline
\end{tabular}

Berdasarkan hasil uji-t menunjukan bahwa telur tetas yang difumigasi dan tanpa fumigasi tidak berpengaruh nyata $(p>0,05)$ terhadap fertilitas. Hal tersebut menunjukan telur yang difumigasi dan tanpa fumigasi adalah sama, walaupun secara numerik persentase fertilitas telur parent stock ayam broiler yang difumigasi lebih tinggi jika dibandingkan dengan telur tetas tanpa fumigasi. Hal ini diduga karena sebelum dilakukan fumigasi, telur tetas yang diperoleh dari kandang pemeliharaan terlebih dahulu diseleksi, lalu dibersihkan dari kotoran-kotoran yang menempel pada kerabang telur. Mikroorganisme pada telur tetas yang difumigasi jelas akan sangat kecil jumlahnya bahkan tidak ada jika dibandingkan dengan telur yang tidak difumigasi karena telur tetas yang difumigasi melewati dua tahap pembersihan yaitu pembersihan manual dan fumigasi. Sudaryani dan Santoso (2003) menyatakan bahwa fumigasi bertujuan untuk mengurangi kontaminan bibit bakteri yang menempel pada permukaan telur agar telur benar-benar terbebas dari bakteri maupun jamur.

Fertilitas telur tetas dapat diketahui dengan melakukan peneropongan (candling). Kebiasaan di perusahaan pembibitan parent stock ayam broiler, peneropongan dilakukan pada hari ke-19. Hal ini dikarenakan agar penoropongan dilakukan secara efektif dan seragam, telur yang ditetaskan diperusahaan dalam jumlah yang banyak. Selain itu, ruang inkubator tidak bisa di buka tutup terlalu sering karena 
dapat mengakibatkan tidak konstannya suhu dan kelembaban dalam mesin tetas. Saleh dan Isyanto (2011) menyatakan bahwa tanda telur fertil bila dilihat dengan menggunakan alat peneropong (candling) akan tampak perkembangan embrio didalam telur tersebut yang bisa berupa bintik hitam, atau seperti sarang lebah, dan pembuluh darah merah juga tampak jelas.

Menurut Wilson (2003) bahwa upaya untuk meningkatkan nilai fertilitas dan ayam tetas telur dapat dilakukan melalui kegiatan sanitasi mesin tetas, fumigasi, maupun penyemprotan cairan desifektas untuk membunuh kuman-kuman atau organisme yang terdapat pada peralatan penetasan maupun yang menempel pada kulit telur.

\section{B. Persentase Daya Tetas Telur Parent Stock Ayam Broiler}

Daya tetas ditentukan berdasarkan jumlah telur tetas yang menetas dari sejumlah telur - telur tetas yang tunas atau fertil (Djanah, 1998). Daya tetas adalah angka yang menunjukan tinggi rendahnya kemampuan telur untuk menetas. Daya tetas telur parent stock ayam broiler yang difumigasi dan tanpa fumigasi disajikan pada Tabel 2.

Tabel 2. Persentase Daya Tetas Telur Parent Stock Ayam Broiler yang di Fumigasi dan Tanpa Fumigasi (\%)

\begin{tabular}{ccc}
\hline Ulangan & \multicolumn{2}{c}{ Perlakuan } \\
\cline { 2 - 3 } & $\begin{array}{c}\text { Telur tetas yang } \\
\text { difumigasi }\end{array}$ & Telur tetas yang tidak difumigasi \\
\hline 1 & 90 & 55.6 \\
3 & 90 & 80 \\
4 & 100 & 100 \\
5 & 88.9 & 100 \\
6 & 100 & 71.4 \\
7 & 77.8 & 100 \\
8 & 100 & 87.5 \\
9 & 100 & 77.8 \\
10 & 100 & 88.9 \\
Rataan & 100 & 100 \\
\hline
\end{tabular}

Berdasarkan hasil uji-t telur tetas yang difumigasi dan tanpa fumigasi tidak berpengaruh nyata $(p>0,05)$ terhadap daya tetas. Hal tersebut menunjukan telur yang difumigasi dan tanpa fumigasi adalah sama, walaupun secara numerik persentase daya tetas telur parent stock ayam broiler yang difumigasi lebih tinggi jika dibandingkan dengan telur tetas tanpa fumigasi. Hal tersebut disebabkan semua telur yang ditetaskan sebelum dimasukan kedalam ruang pendingin (colling room), ruang inkubator (setter), dan ruang penetasan (hatcher) dibersihkan dari kotoran-kotoran yang melekat pada kulit telur. walaupun demikian telur yang tidak difumigasi tidak menjamin pada kerabang telurnya tidak terdapat mikroorganisme. Mikroorganisme yang terdapat pada kerabang telur yang difumigasi akan mati karena pengaruh dari penguapan bahan fumigasi yaitu kalium permanganate $(\mathrm{KMnO} 4)$ atau biasa disebut 
dengan Pottassium carbonat dan $\mathrm{CH}_{2} \mathrm{O} /$ Formalin sehingga telur yang difumigasi akan terbebas dari mikroorganisme. Menurut Agus dkk (2001) telur yang bersih mempunyai daya tetas yang lebih tinggi dibandingkan telur yang kotor, karena telur yang kotor mengandung mikroorganisme yang akan masuk kedalam telur pada proses penetasan, sehingga menurunkan daya tetas.

Jika telur terbebas dari mikroorganisme, maka embrio yang ada pada telur yang dibuahi (fertil) akan tumbuh dan berkembang sampai dengan telur menetas. Menurut Bell dan Weaver (2002), jumlah telur tetas yang dibuahi (fertil) berpengaruh terhadap jumlah telur yang menetas. Selain itu, Mukhlisah (2014) juga menambahkan bahwa telur tetas yang tidak dimasukan kedalam ruang fumigasi akan berdampak negatif pada kerabang telur, disebabkan mikroorganisme akan merusak kerabang telur dan pada akhirnya embrio dalam telur juga akan terserang oleh mikroorganisme yang menyebabkan kematian pada embrio. Kartasudjana dan Suprijatna (2006) juga menyatakan bahwa kondisi kerabang telur sangat erat hubungannya dengan tingkat fertilitas dan daya tetas telur.

\section{Persentase Hasil Tetas Telur Parent Stock Ayam Broiler}

Hasil tetas adalah persentase jumlah telur yang menetas dari jumlah telur yang ditetaskan. Hasil tetas telur parent stock ayam broiler yang difumigasi dan tanpa fumigasi disajikan pada Tabel 3 .

Tabel 3. Persentase Hasil Tetas Telur Parent Stock Ayam Broiler yang di Fumigasi dan Tanpa Fumigasi (\%)

\begin{tabular}{ccc}
\hline \multirow{2}{*}{ Ulangan } & \multicolumn{2}{c}{ Perlakuan } \\
\cline { 2 - 3 } & $\begin{array}{c}\text { Telur tetas yang } \\
\text { difumigasi }\end{array}$ & Telur tetas yang tidak difumigasi \\
\hline 1 & 90 & 50 \\
2 & 90 & 80 \\
3 & 100 & 100 \\
4 & 80 & 100 \\
5 & 100 & 50 \\
6 & 70 & 90 \\
7 & 100 & 70 \\
8 & 100 & 70 \\
9 & 90 & 80 \\
10 & 90 & 80 \\
\hline Rataan & $91 \pm 9,9$ & $77 \pm 17,7$ \\
\hline
\end{tabular}

Berdasarkan hasil uji-t menunjukan bahwa telur tetas parent stock ayam broiler yang difumigasi dan tanpa fumigasi tidak berpengaruh nyata $(p>0,05)$ terhadap hasil tetas. Telur tetas yang difumigasi memilki hasil tetas yang lebih baik jika dibandingkan dengan telur tetas yang tidak difumigasi. Hal ini dikarenakan penggunaan fumigasi pada telur akan menekan perkembangan mikroorganisme yang dapat menyebabkan penurunan daya tetas telur. Menurut Mahfudz (2006) bahwa desinfektan secara aktif akan menekan jumlah mikroorganisme seperti bakteri, jamur, protozoa, dan virus yang dapat menyebabkan penurunan daya tetas.

Tingginya daya tetas telur yang difumigasi dibandingkan dengan telur yang 
tidak difumigasi diduga karena banyaknya kematian embrio pada proses penetasan. Banyaknya jumlah telur tetas yang menetas karena diperoleh dari jumlah telur yang fertil dan embrio yang hidup dan bertumbuh hingga menetas.

Proses fumigasi pada telur tetas dapat menghasilkan telur tetas dalam jumlah banyak yang akhirnya akan menghasilkan DOC (Day Old Chicken) yang banyak pula. Secara ekonomi usaha ini mempunyai peluang untuk mendapatkan peningkatan nilai jual dari telur konsumsi menjadi telur tetas. Menurut Sutiyono dkk. (2006) bahwa proses penetasan yang memiliki daya tetas telur yang tinggi merupakan harapan dari setiap penetasan telur dalam usaha pembibitan ayam agar lebih efisien. Menurut Mahfudz (2006) dalam proses penetasan secara umum hanya telur berkualitas baik yang dipilih untuk diinkubasikan, ini berarti hanya telur yang bersih dan memiliki kualitas kerabang yang utuh saja yang layak ditetaskan untuk menghasilkan persentase daya tetas yang baik.

\section{KESIMPULAN}

Dapat disimpulkan bahwa telur tetas yang difumigasi dan tanpa fumigasi tidak berpengaruh nyata $(p>0,05)$ terhadap fertilitas, daya tetas dan hasil tetas, namun secara numerik hasil tetas yang diperoleh untuk telur yang difumigasi lebih baik jika dibandingkan dengan telur yang tidak difumigasi.

\section{DAFTAR PUSTAKA}

Agus, G.T.K., K.A. Agus, A. Dinawati dan U.T. Dipo. 2001. Mesin Tetas. Cetakan 1.Agromedia Pustaka, Jakarta.
Bell, D.D dan W.D. Weaver. 2002. Commercil Chicken Meat and Egg Production. Academic Publisher. United States of America.

Direktorat Jenderal (Dirjen) Peternakan. 2008. Petunjuk Teknis Pelaporan Pembimbitan Ayam Ras. Jakarta.

Djanah, D. 1998. Beternak Ayam.Yasaguna. Surabaya.

Fujiawati, W. D., Sujana, E., dan Darana, S. 2012. Pengaruh konsentrasi asap cair tempurung kelapa pada fumigasi telur itik terhadap daya tetas dan kematian embrio. Students e-Journal, 1(1): 14.

Islam, M.S., M. A. R. Howlider., F. Kabir dan Alam. 2002. Comparative Assessment of Fertility and Hatchability of Barred Playmounth Rock. White leghorn. Rhode island red and White rock hen. Int. Poult Sci. 1(4):85-90

Kartasudjana, R., 2001. Penetasan Telur. Proyek Pengembangan Sistem dan Standar Pengelolaan Smk direktorat Pendidikan Menengah Kejuruan.Departemen Pendidikan Nasional. Jakarta.

Mahfudz, L.D. 1998. Manajemen Penetasan Telur Unggas. Fakultas Peternakan Universitas Diponegoro

Mahfudz, L.D. 2004. Hidrogen Peroksida Sebagai Desinfektan Pengganti Gas Formaldehyde pada Penetasan Telur Ayam. Karya Ilmiah. Fakultas Peternakan Universitas Diponegoro. Semarang 
Mahfudz, L. D. 2006. Hidrogen Peroksida Sebagai Pengganti Gas Formaldehyde Pada Penetasan Telur Ayam. Jurnal Protein. 13 (2): 128-133.

Mukhlisah, A.N. 2014. Pengaruh Level Ekstrak Daun Melinjo (Gnetum Gnemon Linn) Dan Lama Penyimpanan Yang Berbeda Terhadap Kualitas Telur Itik.

Nafiu, L.O., M. Rusdin., A.S. Aku. 2014. Daya Tetas dan Lama Menetas Telur Ayam Tolaki pada Mesin Tetas dengan Sumber Panas yang Berbeda. Fakultas peternakan, universitas halu oleo. Kendari. 1(1).

Nandhra, I P., E. Sudjarwo dan A. A. Hamiyanti. 2014. Pengaruh penggunaan ekstrak daun sirih (Piper Betle linn.) pada pencelupan telur tetas itik mojosari terhadap daya tetas dan mortalitas embrio. Jurnal ilmu-ilmu peternakan. 25(1):16-23.

Pagala, M.A., Muladno, C.Sumantri \& S. Murtini. 2013.Association of $\mathrm{Mx}$ Gene Genotype with Antiviral and Production Traits in Tolaki Chicken.Int. J. Poult Sci. 12 (12): 735739.

Pagala, MA, AM.Tasse, N.Ulupi. 2015. Association of cGH EcoRV Gene with Production in Tolaki Chicken. IJSBAR. 24(7):88-95.

Pamungkas, R. S., Ismoyowati, dan Santosa. S. A. 2013. Kajian bobot tetas, bobot badan, umur 4 dan 8 minggu serta korelasinya pada berbagai itik lokal (anasplathyrynchos) dan itik manila (cairinamoscata) jantan jurnal ilmiah peternakan, 1(2):488500 .

Pasaribu, L. 2015. Pengaruh Lama Penyimpanan Hatching Egg ( $\mathrm{He})$ terhadap Daya Tetas (Hatchibility) di PT. Charoen Pokphand Jaya Farm Unit Hatchery I Medan.,Program Studi Peternakan Jurusan Budidaya Tanaman Pangan Politeknik Pertanian Negeri Payakumbuh. Payakumbuh..

Rahayu, H.S.I., I. Suherlandani. I. Supriatna. 2005. Kualitas telur tetas ayam merawang dengan waktu pengulangan inseminasi buatan yang berbeda. Fakultas peternakan institute pertanian Bogor, J. Indon. Trop. Anim. Agric., 30(3):1-7.

Saleh, D. M. dan A. Y. Isyanto,. 2011. Pengaruh Lama Penyimpanan terhadap Motilitas dan Fertilitas Spermatozoa Ayam Kate Lokal Cakrawala Galuh. 1 (6) : 1-6

Sudjarwo,E. 2012. Pengaruh Lama Penyimpanan Telur Ayam Buras Terhadap Fertilitas, Daya Tetas Telur Dan Berat Tetas. Jurnal Agrisistem. 6 (2): 97-102..

Suprijatna, E., U. Atmomarsono, dan R. Kartasudjana. 2008. Ilmu Dasar Ternak Unggas. Penebar Swadaya, Jakarta.

Wilson, H.R. 2003. Dairy and poultry science d cooperative extension service, institute of food and agricultural science (IFAS), University of Florida, Guineville. 